\title{
HUBUNGAN MOTIVASI BELAJAR DENGAN HASIL BELAJAR PADA MATA PELAJARAN KIMIA
}

\author{
I Putu Budiariawan
}

SMA Negeri 2 Negara

\section{A R T I C L E I N F O}

Article history:

Received 05 October 2019

Received in revised form

7 October 2019

Accepted 9 October 2019

Available online 12 October 2019

\section{Kata Kunci:}

Hasil belajar, motivasi belajar, pelajaran kimia

\begin{abstract}
ABSTRAK
Penelitian ini bertujuan untuk: (1) mendeskripsikan dan menjelaskan hubungan antara motivasi belajar dengan hasil belajar kimia siswa. (2) mengetahui dan menjelaskan besarnya koefisien korelasi antara motivasi belajar dengan hasil belajar kimia siswa. Penelitian ini menggunakan pendekatan kuantitatif. Populasi penelitian ini adalah seluruh siswa kelas XI MIPA di SMA Negeri 2 Negara tahun pelajaran 2017/2018 dan sampel penelitian berjumlah 72 orang dengan menggunakan teknik cluster sampling. Data dikumpulkan menggunakan instrumen penelitian berupa kuesioner motivasi belajar yang terdiri dari 20 pernyataan positif dan 15 pernyataan negatif dan data hasil belajar siswamenggunakan nilai UAS siswa. Hasil penelitian menunjukkan bahwa(1) terdapat hubungan yang positif dan signifikan antara motivasi belajar siswa pada pembelajaran kimia dengan hasil belajar kimia siswa. (2) Besarnya koefisien korelasi yang diperoleh yaitu sebesar 0,391, yang berarti $r$ hitung yang diperoleh lebih besar dibandingkan dengan $r$ tabel yang telah ditentukan pada taraf signifikansi $5 \%$ yaitu 0,229 , sehingga Hipotesis $\mathrm{Nol}\left(\mathrm{H}_{0}\right)$ dalam penelitian ini dapat ditolak.Berdasarkan hasil pemaparan diatas, dapat disimpulkan bahwa terdapat hubungan yang positif dan signifikan antara motivasi belajar pada mata pelajaran kimia dengan hasil belajar kimia siswa.
\end{abstract}

\begin{abstract}
This study aims to: (1) describe and explain the relationship between learning motivation and student chemistry learning outcomes. (2) knowing and explaining the magnitude of the correlation coefficient between learning motivation and student chemistry learning outcomes. This study uses a quantitative approach. The population of this study was all students of class XI MIPA in SMA Negeri 2 Negara the academic year $2017 / 2018$ and the study sample amounted to 72 people using the cluster sampling technique. The data were collected using the research instrument in the form of a learning motivation questionnaire consisting of 20 positive statements and 15 negative statements and student learning outcomes data using the student UAS value. The results showed that (1) there was a positive and significant relationship between students' learning motivation in chemistry learning and student chemistry learning outcomes. (2) The magnitude of the correlation coefficient obtained is equal to 0.391 , which means that the calculated $r$ is greater than the $r$ table that has been determined at the $5 \%$ significance level of 0.229 , so the Zero Hypothesis (H0) in this study can be rejected. Based on the results of the explanation above, it can be concluded that there is a positive and significant relationship between motivation to learn on chemistry subjects and student chemistry learning outcomes.
\end{abstract}

Keywords: Chemistry Learning, Learning Outcomes, Learning Motivation

${ }^{1}$ Corresponding author.

E-mail: putubudiawan@gmail.com 


\section{PENDAHULUAN}

Motivasi belajar merupakan salah satu faktor keberhasilan siswa dalam mencapai hasil belajar yang maksimal. Siswa yang memiliki motivasi tinggi untuk belajar akan lebih baik dalam menerima pelajaran serta sikap yang ditimbulkan oleh siswa akan menjadi lebih positif dalam pembelajaran (Sardiman, 2014). Sangat penting untuk membentuk motivasi belajar dalam diri siswa agar terjadi perubahan belajar ke arah yang lebih positif. Darsono (dalam Ayu Nurmala, 2014) menyatakan terdapat beberapa faktor yang mempengaruhi motivasi dalam belajar, yaitu: (a) Cita-cita atau aspirasi siswa;

(b) Kemampuan belajar; (c) Kondisi siswa; (d) Kondisi lingkungan; (e) Unsur-unsur dinamis dalam belajar; (f) Upaya guru dalam pembelajaran. Dalam menilai motivasi pada siswa diperlukan adanya dimensi pengukuran. Menurut Sardiman (2014), motivasi belajar siswa meliputi beberapa ciriciri sebagai berikut: (a) Tekun menghadapi tugas,

(b) Ulet menghadapi kesulitan, (c) Menunjukkan minat terhadap bermacam-macam masalah orang dewasa, (d) Lebih senang bekerja mandiri, (e) Dapat mempertahankan pendapatnya, (f) Cepat bosan pada tugas-tugas yang rutin, (g) Tidak mudah melepaskan hal yang diyakini, (h) Senang mencari dan memecahkan masalah pada soal - soal.

Mata pelajaran kimia merupakan salah satu mata pelajaran yang kurang diminati oleh kebanyakan peserta didik SMA (Subagia, 2014). Hal ini disebabkan karena kimia dianggap sebagai salah satu mata pelajaran yang sulit, yang kadang-kadang membuat siswa tidak mau belajar kimia lebih lanjut. Pandangan siswa yang menganggap bahwa pelajaran kimia sulit menyebabkan motivasi siswa dalam belajar kimia tidak ada. Seorang siswa yang tidak termotivasi dengan baik saat pembelajaran akan melakukan kegiatan belajar yang cenderung lebih pasif dibandingkan dengan siswa yang termotivasi dengan baik dalam belajar. Berdasarkan penelitian pendahuluan yang dilakukan di SMA Negeri 2 Negara, didapatkan bahwa hasil belajar ujian akhir semester pada mata pelajaran kimia siswa kelas XI MIPA di SMA Negeri 2 Negara tahun pelajaran 2016/2017 masih rendah. Hal ini terlihat dari jumlah siswa yang memperoleh nilai diatas KKM pada ujian akhir semester hanya 13 siswa dengan persentase 9,02\%, sedangkan 131 siswa lainnya nilai ujian akhir semester yang diperoleh masih dibawah standar kriteria ketuntasan minimal yang telah ditetapkan oleh sekolah. Namun pada saat peneliti melihat proses pembelajaran yang berlangsung, siswa yang memiliki nilai hasil belajar yang rendah memiliki aktivitas belajar yang baik ketika proses pembelajaran berlangsung. Mereka aktif dalam proses pembelajaran dan berani bertanya ketika belum memahami materi yang diberikan. Secara teori, siswa yang memiliki motivasi dalam belajar tentu saja akan aktif dalam pembelajaran. Hal ini dikarenakan motivasi berpangkal dari kata "motif" yang dapat diartikan daya penggerak yang ada di dalam diri seseorang untuk melakukan aktivitasaktivitas tertentu demi tercapainya suatu tujuan (Sardiman, 2012).Berdasarkan hal inilah, maka dirasakan perlu mengadakan penelitian lebih lanjut untuk mengetahui hubungan antara motivasi belajar pada mata pelajaran kimia dengan hasil belajar yang diperoleh siswa.

\section{METODE PENELITIAN}

Penelitian ini diklasifikasikan ke dalam penelitian kuantitatif dengan mengadopsi rancangan penelitian korelasional. Pada penelitian ini tidak dilakukan perlakuan terhadap subjek penelitian. Peneliti hanya mengukur derajat keterhubungan antara variabel motivasi belajar dan hasil belajar siswa. Penelitian ini melibatkan satu variabel bebas dan satu variabel terikat. Dalam penelitian ini desain penelitian yang digunakan adalah korelasi yaitu meneliti hubungan atau pengaruh sebab akibat antara motivasi belajar dengan hasil belajar kimia siswa. Adapun desain dari penelitian ini adalah seperti gambar berikut.

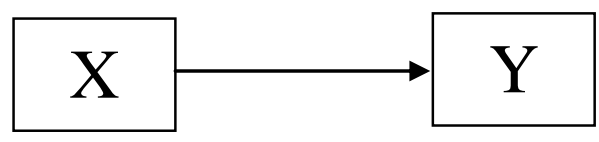

Gambar 1

Keterangan:

Desain Penelitian (diadaptasi dari Sugiyono, 2014)

$\mathrm{X} \quad=$ Motivasi Belajar

$\mathrm{Y} \quad=$ Hasil Belajar Kimia

$\mathrm{r}_{\mathrm{xy}}=$ korelasi antara motivasi belajar dengan hasil belajar 
Populasi pada penelitian ini adalah seluruh siswa kelas XI MIPA SMA Negeri 2 Negara tahun pelajaran 2017/2018 yang berjumlah 150 orang yang tersebar ke dalam 4 kelas. Sampel adalah bagian dari jumlah dan karakteristik yang dimiliki oleh populasi tersebut (Sugiyono, 2012). Pada penelitian ini, tekhnik sampling yang digunakan adalah Cluster Sampling. Cluster Sampling merupakan teknik memilih sebuah sampel dari kelompok - kelompok unit yang kecil. Teknik ini dipakai karena tidak mungkin dilakukan teknik acak. Pemilihan sample dilakukan dengan memilih 2 kelas yang ada sebagai sampling dengan dilakukan pengundian. Hal ini dilakukan untuk menghemat waktu penelitian, serta dikarenakan populasi yang homogen. Setelah dilakukan pengambilan sampel terpilih siswa kelas XI MIPA 1 dan XI MIPA 2. Sampel penelitian terdiri dari 2 kelas, dengan jumlah 72 siswa. Lokasi penelitian dilakukan di SMA Negeri 2 Negara yang terletak di Jalan Sugianyar, Civic Centre, Dauhwaru, Jembrana, pada semester genap tahun pelajaran 2017/2018.

Pengumpulan data dilakukan sebanyak 2 tahap yaitu, 1) pengumpulan data motivasi belajar siswa dan 2) pengumpulan data hasil belajar kimia siswa. Instrumen penelitian yang digunakan dalam penelitian ini adalah dengan menggunakan instrumen kuesioner motivasi belajar.Dokumentasi digunakan untuk memperoleh data nama dan nilai hasil belajar yang diperoleh peserta didik selama proses pembelajaran. Selain itu dokumentasi digunakan sebagai bukti pelaksanaan penelitian, yang mana bukti tersebut berupa foto selama proses penelitian. Penelitian ini menggunakan dua teknik analisis data yaitu analisis deskriptif dan analisis korelasi sederhana. Analisis deskriptif digunakan untuk menggambarkan motivasi belajar dan hasil belajar kimia. Analisis korelasi digunakan untuk menentukan hubungan dan besarnya koefisien korelasi prediktor dengan kriterium.

\section{HASIL PENELITIAN}

Deskripsi umum data hasil penelitian motivasi belajar dan hasil belajar kimia siswa di SMA Negeri 2 Negara, ditinjau berdasarkan skor tertinggi, skor terendah, standar deviasi, nilai rata-rata (mean), nilai tengah (median), dan nilai terbanyak (modus) dapat dilihat pada tabel 1.

Tabel 1

Deskripsi Umum Motivasi Belajar dan Hasil Belajar

\begin{tabular}{ccc}
\hline Statistik & Motivasi Belajar & Hasil Belajar \\
\hline Valid & 72 & 72 \\
Missing & 0 & 0 \\
Mean & 97.56 & 61.36 \\
Median & 95.50 & 63.00 \\
Modus & 95 & 80 \\
Std. Deviation & 11.455 & 20.898 \\
Range & 49 & 74 \\
Nilai terendah & 75 & 23 \\
Nilai Tertinggi & 124 & 97 \\
\hline
\end{tabular}

Gambaran mengenai karakteristik distribusi skor motivasi belajar, berikut disajikan skor tertinggi, skor terendah, standar deviasi, mean, median, modus. Motivasi belajar memiliki skor tertinggi sebesar 124 dan skor terendah sebesar 75, hasil analisis harga Mean (M) sebesar 97.56, Median (Me) 95,50, modus (Mo) sebesar 95, dan Standar Deviasi (SD) sebesar 11.455.Data variabel hasil belajar diperoleh melalui nilai UAS hasil belajar siswa dari mata pelajaran kimia dengan jumlah serponden sebanyak 72 siswa. Berdasarkan data variabel yang didapat, diperoleh skor tertinggi sebesar 97 dan skor terendah sebesar 23. Hasil analisis harga Mean (M) sebesar 61.36, Median (Me) sebesar 63.00, Modus (Mo) sebesar 80 dan Standar Deviasi (SD) sebesar 20.898.

Berdasarkan analisis yang dilakukan, besarnya hubungan motivasi belajar dengan hasil belajar kimia yang dihitung dengan menggunakan teknik korelasi product moment dari pearson sebesar 0,391 . Hasil $r$ hitung yang diperoleh menunjukkan adanya hubungan yang rendah antara motivasi belajar dengan hasil belajar siswa kelas XI MIPA di SMA Negeri 2 Negara pada mata pelajaran kimia.

Hasil perhitungan yang didapat menunjukkan bahwa $r$ hitung yang didapat yaitu 0,391 lebih besar daripada $r$ tabel pada taraf signifikansi 0,05 yaitu 0,229 dan pada taraf signifikansi $1 \%$ yaitu 0,297 . Besarnya $r$ hitung yang didapat menunjukkan bahwa terdapat hubungan antara motivasi belajar kimia siswa dengan hasil belajar kimia, sehingga dapat disimpulkan bahwa H0 dapat ditolak sehingga dapat ditarik kesimpulan terdapat hubungan yang positif dan signifikan antara motivasi belajar yang dimiliki oleh siswa dengan hasil belajar kimia siswa. 


\section{PEMBAHASAN}

Penelitian ini bertujuan untuk mengetahui hubungan antara motivasi belajar dengan hasil belajar kimia siswa kelas XI MIPA di SMA Negeri 2 Negara dan besar koefisien korelasi antara motivasi belajar dengan hasil belajar. Motivasi belajar merupakan daya penggerak dalam diri siswa untuk mampu mencapai hasil belajar yang optimal sehingga tujuan yang dikehendaki dalam belajar dapat tercapai. Siswa yang memiliki motivasi yang tinggi dalam belajar akan mampu melaksanakan kegiatan belajar dengan tanggung jawab dan keyakinan penuh bila dibandingkan dengan siswa yang memiliki motivasi belajar yang rendah, sehingga hasil belajar yang dicapai mampu didapat secara optimal.

Hasil penelitian secara deskriptif menunjukkan bahwa, siswa kelas XI MIPA di SMA Negeri 2 Negara memiliki tingkat motivasi belajar yang tinggi pada mata pelajaran kimia, namun hasil belajar yang diperoleh tergolong sedang. Hal ini terlihat dari rerata total skor motivasi belajar yang diperoleh siswa yaitu pada 97,56, sedangkan rerata hasil belajar yang diperoleh oleh siswa pada mata pelajaran kimia menunjukkan hasil yaitu sebesar 61,36.

Siswa memperoleh hasil belajar yang kurang maksimal disebabkan karena tampak kurang latihan dalam mencari dan memecahkan masalah soal- soal terutama dalam menjawab soal-soal latihan pada LKS, mudah terpengaruh dengan jawaban teman dan tidak ragu- ragu dalam mengikuti pendapat ataupun jawaban dari teman meskipun jawaban atau pendapat temannya belum tentu benar. Siswa tampak kurang latihan dalam mencari dan memecahkan soal- soal terlihat dari jawaban kuesioner siswa pada butir pernyataan no 33. Hasil yang diperoleh 67\% siswa menjawab kadangkadang senang mencari soal-soal kimia yang sulit di LKS untuk diselesaikan. Pada butir pernyataan no 35 diperoleh hasil 40\% siswa menjawab kadang-kadang senang mendapatkan soal-soal baru dan berusaha untuk menjawab dengan benar. Siswa kurang latihan dalam menjawab soal-soal yang terdapat pada LKS, sehingga ketika UAS menjadi kelabakan dalam menjawab soal-soal yang diberikan oleh guru. Senada dengan Oemar Hamalik (2005) menyatakan bahwa latihan menjawab soal-soal sangat bermanfaat dalam proses pembelajaran karena dapat memberikan pengalaman pendidikan bagi para siswa, mampu memantapkan hasil belajar yang diperoleh, penguasaan aspek-aspek perubahan tingkah laku siswa, mampu mengembangkan kemampuan berfikir untuk dapat memecahkan masalah-masalah yang dihadapi baik secara individu maupun kelompok, mampu mambantu cara pembelajaran yang lebih efektif; seperti mengingat, meniru dan otomatisasi jawabanjawaban, sehingga mampu memaksimalkan tercapainya hasil belajar.

Siswa kurang memiliki rasa percaya diri terhadap jawaban yang dibuat dan lebih bergantung terhadap jawaban dari orang lain. Pernyatan dapat dilihat dari jawaban kuesioner siswa pada butir pernyataan nomor 27, diperoleh hasil 65\% siswa menjawab mudah terpengaruh dengan jawaban teman. Pada butir pernyataan nomor 28 diperoleh 46\% siswa menjawab tidak ragu-ragu mengikuti pendapat teman ketika mengerjakan ulangan maupun tugas yang diberikan oleh guru. Hal ini sejalan dengan penelitian yang dilakukan oleh Murtiningsih (2017) yang menyatakan bahwa siswa yang tidak memiliki rasa percaya diri, akan sangat susah untuk meyakini kemampuan dan usaha-usaha yang telah dicapainya, sehingga mempengaruhi kualitas hasil belajar siswa yang diperoleh. Senada dengan penelitian yang dilakukan oleh Sari, Sunarno, \& Sarwanto (2018) yang menyatakan bahwa aspek percaya diri siswa memberi sumbangan sebesar $55,28 \%$ dalam mendorong motivasi siswa dalam belajar. Sari, et al. (2018) menyatakan bahwa rasa percaya diri siswa dapat dilihat dari bagaimana siswadalam menyelesaikan tugas yang diberikan baik secara individu maupun kelompok, menyelesaikan soal-soal dengan percaya diri dan tidak menjiplak pekerjaan teman dan lain sebagainya. Rasa percaya diri yang rendah pada siswa akan mempengaruhi motivasi belajar yang dimiliki oleh siswa tersebut sehingga secara tidak langsung akan mempengaruhi hasil belajar yang diperoleh.

Sejalan dengan pendapat Sardiman (2012) menyatakan bahwa dalam kegiatan belajar mengajar, hasil belajar yang diperoleh oleh siswa akan berhasil baik apabila seorang siswa mampu mempertahankan pendapat yang dia miliki, ketika sudah yakin dan dipandang cukup rasional.

Beberapa faktor diatas menjadi penyebab siswa memperoleh hasil belajar yang tidak begitu baik, meskipun rata - rata siswa memiliki motivasi belajar yang tinggi dalam pembelajaran kimia. Hal ini dapat dijadikan pedoman untuk guru, agar siswa tidak hanya sekedar memiliki motivasi yang tinggi dalam belajar tetapi juga harus memperoleh motivasi yang tepat dan optimal didalam belajar sehingga siswa mampu memperoleh atau mencapai tujuan belajar yang maksimal.

Hasil uji analisis yang telah dilakukan menggunakan uji korelasi sederhana dengan bantuan program SPSS PC 16.0 for Windows, menunjukkan bahwa ada korelasi yang positif dan signifikan antara hubungan motivasi belajar dengan hasil belajar kimia siswa kelas XI MIPA di SMA Negeri 2 Negara. Korelasi yang positif dan signifikan terlihat dari nilai $r$ hitung yang didapat lebih besar dari nilai $r$ tabel pada taraf signifikansi $1 \%$ dan pada taraf signifikansi $5 \%$ yaitu sebesar 0,391 > 0,297 > 
0,229. Maka hipotesis nol (H0) pada penelitian ini ditolak. Jadi ada korelasi yang positif antara motivasi belajar dengan hasil belajar kimia. Korelasi yang positif berarti semakin tinggi motivasi belajar yang dimiliki siswa, maka akan semakin baik pula hasil belajar yang diperoleh oleh siswa tersebut. Hasil penelitian ini sejalan dengan penelitian yang dilakukan oleh Rozana Ulfah, K., Santoso, A., \& Utaya, S., (2016), yang menyatakan bahwa ada korelasi positif antara motivasi belajar dengan hasil belajar siswa. Penelitian yang dilakukan oleh Fatimah \& Noviana (2017) yang menyatakan bahwa terdapat hubungan yang positif dan signifikan antara motivasi belajar dengan prestasi belajar kimia di kelas XI MIPA SMAN 1 Gedangan.

Secara teoritis, keberhasilan siswa dalam belajar dipengaruhi oleh berbagai faktor yang salah satunya dipengaruhi oleh motivasi dalam belajar. Penelitian Dimyati dan Mudjiono (2013) menyatakan bahwa seseorang yang memiliki motivasi yang tinggi dalam belajar, maka hasil belajar yang akan didapat orang tersebut akan semakin baik. Motivasi belajar yang tinggi tercermin dari ketekunan yang tidak mudah patah dalam mencapai kesuksesan meski dihadang oleh berbagai kesulitan, tidak mudah terjebak pada kegiatan yang bersifat berulang- ulang begitu saja sehingga menjadi kurang kreatif, serta mampu mempertahankan pendapatnya dan senang dalam menyelesaikan masalah- masalah yang ada dan mampu menyelesaikannya. Ketika siswa telah memperoleh motivasi belajar yang tinggi dan tepat, hal ini akan menggiatkan siswa dalam aktivitas belajarnya serta mampu melaksanakan kegiatan belajar dengan penuh keyakinan dan tanggung jawab dibandingkan siswa dengan motivasi belajar yang rendah. Di dalam proses pembelajaran siswa akan menemukan berbagai permasalahan yang dihadapi, sehingga seorang siswa harus memiliki semangat dan motivasi yang tinggi dalam belajar agar mampu mencapai tujuan yang ingin dicapai. Ketika menghadapi suatu permasalahan seorang siswa harus dapat memecahkan masalah yang dihadapinya. Motivasi belajar yang tinggi diharapkan mampu menjadi rekomendasi bagi para pendidik untuk dapat mengarahkan siswamenjadi pelajar yang aktif dalam proses belajar mengajar, serta mampu memberikan motivasi yang tepat dalam proses pembelajaran, sehingga siswa mampu meraih hasil belajar yang maksimal.

Uno (2012) menyatakan terdapat beberapa teknik untuk memberikan motivasi yang tepat untuk dapat digunakan oleh guru dalam pembelajaran, yaitu: (1) pernyataan penghargaan secara verbal terhadap perilaku yang baik atau hasil belajar siswa yang baik, (2) menggunakan nilai ulangan sebagai pemacu keberhasilan,

(3) menimbulkan rasa ingin tahu, (4) memunculkan sesuatu yang tidak diduga, (5) menjadikan tahap dini dalam belajar mudah bagi siswa, (6) menggunakan materi yang dikenal siswa sebagai contoh dalam belajar, (7) menuntut siswa untuk menggunakan hal-hal yang telah dipelajari sebelumnya, (8) menggunakan simulai dan permainan, (9) memberi kesempatan kepada siswa untuk memperlihatkan kemahirannya didpean umum, (10) mengurangi akibat yang tidak menyenangkan dan keterlibatan siswa dalam kegiatan belajar, (11) memperjelas tujuan belajar yang hendak dicapai, (12) merumuskan tujuan-tujuan sementara, (13) memberitahukan hasil kerja yang telah dicapai, (14) membuat suasana persaingan yang sehat di antara para siswa, dan (15) memberikan contoh yang positif, dengan mengurangi kebiasaan memberikan suatu tugas kepada kelas, dan guru meninggalkan kelas untuk melaksanakan pekerjaan lain.

Berdasarkan hasil pembahasan diatas, selain adanya motivasi belajar dalam diri siswa, pendidik diharapkan untuk dapat memperhatikan variabel- variabel lain yang mampu memengaruhi keberhasilan siswa dalam belajar. Selain motivasi belajar, Dimyati dan Mudjiono (2010) mengemukakan banyak variabel- variabel lain yang mampu memengaruhi keberhasilan siswa dalam mencapai hasil belajar yang baik, yaitu siswa harus memiliki sikap terhadap belajar, konsentrasi belajar, kemampuan mengolah bahan belajar, kemampuan menyimpan perolehan hasil belajar, kemampuan menggali hasil belajar yang tersimpan, kemampuan berprestasi, rasa percaya diri siswa, intelegensi dan keberhasilan belajar siswa, kebiasaan belajar siswa, dan cita-cita siswa.

\section{SIMPULAN DAN SARAN}

Berdasarkan hasil analisis pembahasan yang telah dipaparkan mengenai hubungan motivasi belajar dengan hasil belajar siswa kelas XI MIPA di SMA Negeri 2 Negara, maka dapat ditarik simpulan terdapat hubungan positif dan signifikan antara motivasi belajar siswa pada pembelajaran kimia dengan hasil belajar kimia siswa kelas XI di SMA Negeri 2 Negara yang dilihat dari besar koefisien korelasi yang diperoleh yaitu sebesar 0,391, yang berarti $r$ hitung yang diperoleh lebih besar dibandingkan dengan $r$ tabel yang telah ditentukan pada taraf signifikansi $1 \%$ dan $5 \%$ yaitu $0,391>0,297>0,229$, menandakan terdapat hubungan yang positif dan signifikan antara motivasi belajar siswa dengan hasil belajar kimia, sehingga hipotesis nol (HO) dalam penelitian ini dapat ditolak. Hasil belajar siswa pada pembelajaran kimia sedang dikarenakan, siswa kurang latihan dalam 
menjawab soal-soal, kurang memiliki rasa percaya diri terhadap jawaban yang dimilikinya dan lebih bergantung terhadap jawaban dari orang lain.

Berdasarkan hasil-hasil penelitian yang telah dicapai serta simpulan diatas, maka dapat disarankan sebagai berikut, yaitu bagi guru disarankan untuk mampu meningkatkan motivasi siswa agar lebih senang dalam mencari dan berlatih soal- soal serta meningkatkan rasa percaya diri yang dimiliki siswa, dengan memberikan tugas-tugas pembelajaran kimia yang dekat atau berkaitan dengan kehidupan siswa yang mampu memicu keingintahuan siswa, sehingga mau menyelesaikannya dan memberi kesempatan kepada siswa untuk terlibatsecara aktif dalam kegiatan belajar serta memberikan apresiasi kepada siswa setelah selesai menjawab pertanyaan yang diberikan dan tidak menjatuhkan siswa secara langsung ketika salah dalam menjawab ataupun memberikan tanggapan di depan kelas, sedangkan bagi peneliti selanjutnya disarankan untuk melakukan penelitian lebih lanjut mengenai variabel-variabel lain yang mempengaruhi hasil belajar siswa sehingga dapat menyempurnakan penelitian ini.

\section{DAFTAR RUJUKAN}

Aini, Q. (2016). "Pengaruh Motivasi Belajar Intrinsik Dan Ekstrinsik Terhadap Prestasi Belajr Ekonomi Di SMA NW Pancor Lombok Timur Ntb". GaneĆSwara. Vol 10No. 2 September 2016.

Alhadi, S., \& Eka Saputra, W., E., (2017). “The Relationship between Learning Motivation and Learning Outcome of Junior High School Students in Yogyakarta". Advances in Social Science, Education and Humanities Research (ASSEHR), Volume 66, YICEMAP, 2017.

Arikunto, S. (2006). Prosedur Penelitian Suatu Pendekatan Praktik. Jakarta: Rineka Cipta.

Aritonang, K.T. (2008). “Minat Dan Motivasi Pendidikan Penabur. (11). 11-21.

Dalam Meningkatkan Hasil Belajar Siswa". Jurnal

Astuti, F., Redjeki, T., \& Nurhayati, N. D. (2016). "Identifikasi Miskonsepsi dan Penyebabnya Pada Siswa Kelas XI MIA SMA Negeri 1Sukoharjo Tahun Pelajaran 2015/2016 Pada Materi Pokok Stoikiometri". Jurnal Pendidikan Kimia (JPK). Vol. 5. No. 2 Tahun 2016.

Ayu Nurmala, D., Endah Tripalupi, L., Suharsono, N. (2014). "Pengaruh Motivasi Belajar Dan Aktivitas Belajar Terhadap Hasil Belajar Akuntansi”. Jurnal Jurusan Pendidikan Ekonomi. Vol. 4, No: 1, Tahun 2014.

Candiasa, I. M. (2004). Statistik Multivariat Disertai Aplikasi Dengan SPSS. Undiksha: Unit Penerbitan IKIP Negeri Singaraja.

Candiasa, I. M. (2007). Statistik Multivariat. Bahan Ajar. DIKSH. Undiksha Singaraja.

Candiasa, I. M. (2010). Pengujian Instrumen Penelitian Disertai Aplikasi Iteman Dan Bigsteps. Undiksha: Unit Penerbitan Universitas Pendidikan Ganesha.

Daud, F. (2012). "Pengaruh Kecerdasan Emosional (EQ) Dan Motivasi Belajar Terhadap Hasil Belajar Biologi Siswa SMA 3 Negeri Kota Palopo". Jurnal Pendidikan Dan Pembelajaran. Volume 19, Nomor 2, Oktober 2012.

Dimyati dan Mudjiono. (2009). Belajar dan Pembelajaran. Jakarta: PT Rineka Cipta.

Djamarah, S.B. (2008). Psikologi Belajar. Jakarta: Rineka Cipta.

Eva Fitriana, (2016). Hubungan Antara Motivasi Belajar Dengan Hasil Belajar IPS Siswa Kelas IV SDN DI GUGUS

Fatimah Az Zahro, A., \& Noviana Khoirunnisa, R. (2017). "Hubungan Antara Motivasi Belajar dengan Prestasi Belajar Mata Pelajaran Kimia Siswa SMAN 1 Gedangan”. Jurnal Psikologi Pendidikan, Vol 4. No. 3.

Firmansyah, E. (2009). "Hubungan Motivasi Berprestasi Siswa Dengan Hasil Belajar Pendidikan 
Jasmani”. Jurnal Pendidikan ～Jasmani Indonesia. Volume 6, nomor 1, april 2009.

Hamalik, O. (2014). Kurikulum dan Pembelajaran. Jakarta: PT. Bumi Aksara.

Hamdu, G. \& Agustina, L. (2011). "Pengaruh Motivasi Belajar Siswa Terhadap Prestasi Belajar Ipa Di Sekolah Dasar". Jurnal Penelitian Pendidikan. 12(1). 90-96.

Hanafy, M., S. (2014). “Konsep Belajar dan Pembelajaran”. Jurnal Lentera Pendidikan, Vol. 17. No. 1 Juni 2014: 66 - 79 .

Johnstone, A. H. (2000). Teaching Of Chemistry Logical Or Psycology, Chemistry Education: Research and practice in europe, Vol. 1, hal . 9-15.

Kasmadi, I., dan Indraspuri, R. (2010). "Pengaruh Penggunaan Artikel Kimia Dari Internet Pada Model Pembelajaran Creative Problem Solving Terhadap Hasil Belajar Kimia Siswa SMA". Jurnal Inovasi Pendidikan Kimia, (Vol. 4, No. 1). Hlm. 574 -581.

Kean, E. dan Middlecamp, C. (1985). Panduan Belajar Kimia Dasar (Alih Bahasa: A. H Pudjaatmaka). Jakarta: PT. Gramedia.

Lampiran Permendikbud Nomor 81A Tahun 2013 Tentang Implementasi Kurikulum Pedoman Umum Pembelajaran. Jakarta: Kementrian Pendidikan dan Kebudayaan RI.

Marhento, G. (2015). "Pengaruh Persepsi Siswa Tentang Kompetensi Guru Mengajar dan Motivasi Belajar Terhadap Hasil Belajar IPA”. Jurnal Formatif, 1(3): 223-235

Merdekawati, K. (2013). "Pengaruh Kemampuan Matematik Terhadap Prestasi Belajar Kimia”. Jurnal Inovasi Dan Kewirausahaan. Volume 2, No 1 Januari 2013.

Mulyasa, E. (2006). Manajemen Berbasis Sekolah. Bandung: PT Remaja Rosdakarya.

Mulyana, A., Hidayat, S., Serang, U. (2013). "Hubungan Antara Persepsi, Minat, Dan Sikap Siswa Dengan Hasil Belajar Siswa Dalam Pembelajaran PKn”. Jurnal Pendidikan dan Kebudayaan. Vol. 19. Nomor 2, Juni 2013.

Murtiningsih. (2017). "Pengaruh Motivasi Belajar, Sarana Belajar, dan Percaya Diri Terhadap Hasil Belajar IPS Siswa Penerima BSM (Bantuan Siswa Miskin) SMP Negeri di Surabaya”. Jurnal Ekonomi Pendidikan dan Kewirausahaan. Vol. 5., No. 2, Tahun 2017.

Muthoharoh, Munifatun, I. Made Kirna, and Gusti ayu Indrawati. "Penerapan Lembar Kerja Peserta Didik (LKPD) Berbasis Multimedia untuk Meningkatkan Motivasi dan Hasil Belajar Kimia." Jurnal Pendidikan Kimia Indonesia 1.1 (2017): 13-22.

Nurdin. (2015). "Hubungan Motivasi Belajar Terhadap Prestasi Belajar Pendidikan Kewarganegaraan”. Faktor Jurnal Ilmiah Kependidikan. Vol II, No. 2 Juli 2015.

Palupi, R., Anitah, S., Budiyono. (2014). "Hubungan Antara Motivasi Belajar Dan Persepsi Siswa Terhadap Kinerja Guru Dalam Mengelola Kegiatan Belajar Dengan Hasil Belajar Ipa Siswa Kelas VIII Di SMPN N 1 Pacitan". Jurnal Teknologi Pendidikan Dan Pembelajaran. Vol. 2, no. 2, hal. 157-170, edisi april 2014.

Retnawati, H. (2016). Analisis Kuantitatif Instrumen Penelitian (Panduan Peneliti, Mahasiswa, dan Psikometrian). Yogyakarta: Parama Publishing.

Riswanto, A., \& Aryani,S., (2017). "Learning Motivation and Student Achievement: Description Analysis and Relationship Both". Couns- Edu, The International Journal of Counseling and Education, Vol. 2, No, 1, March 2017, pp, 42-47.

Rozana Ulfah, K., Santoso, A., \& Utaya, S., "Hubungan Motivasi Dengan Hasil Belajar IPS". Jurnal Pendidikan: Teori, Penelitian, dan Pengembangan, Volume: 1, Nomor: 8 bulan Agustus Tahun 
2016.

Sari, N., Sunarno, W., \& Sarwanto. ((2018). "Analisis Motivasi Belajar Siswa Dalam Pembelajaran Fisika Sekolah Menengah Atas". Jurnal Pendidikan dan Kebudayaan, Vol. 3, Nomor 1, Juni 2018.

Sardiman. (2005). Interaksi Dan Motivasi Belajar. Jakarta: PT Rineka Cipta.

Sardiman, A. M. (2011). Interaksi Dan Motivasi Belajar Mengajar. Jakarta: Rajawali Pers.

Santyasa, I. W. (2005). Analisis Butir dan Konsistensi Internal Tes. IKIP Negeri Singaraja.

Sardiman, A. M. (2014). Interaksi Dan Motivasi Belajar Mengajar. Jakarta: Rajawali Pers.

Slmaeto. (2003). Belajar Dan Faktor- Faktor Yang Mempengaruhinya. Jakarta: Rineka Cipta.

Slameto. (2010). Belajar Dan Faktor- Faktor Yang Mempengaruhinya. Jakarta: PT Rineka Cipta.

Solina, W., Erlamsyah, \& Syahnir. (2013). "Hubungan Antara Perlakuan Orang Tua dengan Motivasi Belajar Siswa di Sekolah”. Jurnal Ilmiah Konseling. 1(2): 289 - 294.

Subagia, I. W. (2014). "Paradigma Baru Pembelajaran Kimia SMA". Seminar Nasional FMIPA UNDIKSHA IV Tahun 2014.

Sugiyono. (2010). Statistika Untik Penelitian. Bandung: Alfabeta.

Sugiyono. (2014). Statistika Untuk Penelitian. Bandung: Alfabeta.

Sukiniarti. (2006). “Hubungan Motivasi Belajar Dengan Hasil Belajar Pada Mahasiswa Di Pendidikan Jarak Jauh". Jurnal pendidikan, vol. 7, nomor 1, maret 2006. 12-18.

Sulistyo, I. (2016). "Peningkatan Motivasi Belajar Dengan Menerapkan Model Pembelajaran Kooperatif Tgt Pada Pelajaran Pkn". Jurnal studi sosial. Vol 4, No. 1.

Suprihatin, S. (2015). "Upaya Guru Dalam Meningkatkan Motivasi Belajar Siswa”. Jurnal Pendidikan Ekonomi UM Metro. Vol. 3. No. 1, 73 - 82.

Sudijono, A. (2008). Pengantar Evaluasi Pendidikan. Jakarta: PT. Raja Grafindo Persada.

Sukadi. (2006). Guru Powerful Guru Masa Depan. Bandung: Kolbu.

Suparman, Ali. (2008). "Upaya Guru dalam Meningkatkan Minat Belajar Siswa Pada Mata Pelajaran Akuntansi di SMA Mass'udiyah Bandung". Jurnal Ilmiah Pend. Ekonomi Akuntansi. Vol. III, No. 1 Januari.

Supranto, J. (2000). Statistik dan Aplikasi. Jilid 1 Edisi 6. Erlangga: Jakarta.

Sutrisno Hadi. (2004). Statistik, Jilid 3. Yogyakarta: Andi.

Syah, D. (2010). Strategi Belajar Mengajar. Jakarta : Diadit Media.

Syariffudin, A. (2011). "Penerapan Model Pembelajaran Cooperative Belajar dan Faktor-faktor yang Mempengaruhinya". TA'DIB, Vol. XVI, No. 01, Edisi Juni 2011.

Uno, H. B. (2012). Teori Motivasi \& Pengukurannya. Jakarta: Bumi Aksara.

Vera Indriasuari, Ni Luh Putu. (2016). Hubungan Antara Motivasi Belajar dan Fasilitas Belajar dengan Hasil Belajar Kimia Siswa. Skripsi tidak dipublikasikan. Singaraja: Universitas Pendidikan Ganesha 
Wahyudi, K. (2015). "Pengaruh Motivasi Belajar Terhadap Hasil Belajar Siswa Kelas VII-I SMP Negeri 13 Surabaya Pada Materi Produksi, Konsumsi Dan Distribusi". Jurnal Widyaloka IKIP Widyadarma Surabaya. Vol. 2, No. 2, Januari 2015.

Wahyuningsih, F. (2011). Persepsi Siswa Terhadap Pelajaran Biologi Dan Hubungannya Dengan Hasil Belajar Biologi Siswa Kelas X SMA Negeri 1 Percut Sei Tuan Tahun Pembelajaran 2011/2012. Skripsi. Medan: UNIMED.

Yuni Hendra P., A. A. (2015). Pengaruh Motivasi Belajar dan Konsep Diri Terhadap Prestasi Belajar Fisika Siswa Kelas X SMA Negeri 1 Gianyar. Skripsi tidak dipublikasikan. Singaraja: Universitas Pendidikan Ganesha 